\title{
PENGGUNAAN EKSTRAK AKAR JERUJU UNTUK MENINGKATKAN LAJU PERTUMBUHAN DAN SURVIVAL RATE PADA IKAN PATIN DJAMBAL (PANGASIUS DJAMBAL)
}

\author{
Leni Handayani \\ Program Studi Budidaya Perairan Fakultas Pertanian Universitas Darwan Ali Kampus Kuala Pembuang \\ J1. Kihajar Dewantara, Kuala Pembuang Kabupaten Seruyan, Pos 74212 \\ E-mail : leni.handayani@unda.ac.id
}

\begin{abstract}
ABSTRAK
Penelitiaan ini bertujuan Mengetahui pengaruh pemberian ekstrak akar jeruju untuk meningkatkan pertumbuhan dan survival rate ikan patin djambal (Pangasius djambal). Penelitian ini menggunakan 4 perlakuan dan 3 ulangan. Perlakuan yang digunakan adalah perlakuan A (100 gram), perlakuan B (75 gram), perlakuan C (50 gram) dan perlakuan D (tanpa pemberiaan ekstrak). Ikan patin djambal (Pangasius djambal) yang digunakan sebanyak 180 ekor. Penelitiaan ini dilaksanakan pada bulan oktober - desember 2017. Parameter yang diamati dalam penelitian ini adalah laju pertumbuhan relatif, efisiensi pemanfaatan pakan dan kelangsungan hidup serta kualitas air yang dianalisis secara deskriptif. Hasil penelitian menunjukan bahwa pemberiaan ekstrak akar jeruju memberikan pengaruh terhadap laju pertumbuhan relatif ikan uji yang dipeihara, efisiensi pemanfaatan pakan, dan kelangsungan hidup ikan patin djambal (Pangasius djambal). Laju petumbuhan relatif tertinggi terjadi pada perlakuan A yaitu dengan dosis pemberiaan sebesar 100 gram $/ \mathrm{kg}$ pakan. Kualitas air selama masa pemeliharaan masih dapat ditoleransi oleh ikan patin djambal (Pangasius djambal).
\end{abstract}

Kata Kunci : jeruju, ekstrak, pertumbuhan, SR, ikan patin

\section{PENDAHULUAN}

Prospek pengembangan ikan patin djambal (Pangasius djambal) di Kabupaten Seruyan mempunyai peluang yang cukup tinggi. Hal ini dilihat dari banyaknya permintaan pasar terhadap komoditas ini. Tingginya permintaan pasar karena ikan patin merupakan salah satu ikan yang banyak digemari oleh masyarakat setempat karena dagingnya yang enak.

Tingginya permintaan pasar ini yang mendorong para petani ikan untuk melakukan usaha budidaya ikan patin djambal (Pangasius djambal) tersebut. Keberhasilan suatu kegiatan usaha budidaya salah satunya dipengaruhi oleh pakan. Ikan akan dapat tumbuh optimal jika memperoleh makanan dalam jumlah yang cukup dan dengan gizi yang seimbang. Pemberiaan pakan yang baik dan tepat akan menghasilkan pertumbuhan yang baik pula.

Secara umum pertumbuhan merupakan suatu proses biologi yang kompleks yang dipengaruhi oleh faktor luar dan dalam. Faktor dalam umumnya adalah faktor yang sangat sulit untuk dikontrol seperti keturunan, sex,umur, parasit dan penyakit, sedangkan faktor luar yang utama adalah pakan dan kualitas air (Effendi, 2008 dalam Halimah 2014). Pakan merupakan salah satu faktor yang sangat diperhatikan oleh petani ikan, karena sebagian besar dari biaya produksi yang dikeluarkan adalah unutuk biaya pakan. Pemberiaan bahan atau suplemen pada pakan merupakan salah satu alternatif agar pakan yang diberikan pada ikan dapat dimanfaat kan secara optimal oleh ikan sehingga pertumbuhan ikan dapat lebih meningkat. Salah satu penelitiaan yang pernah dilakukan oleh Rahayu, 2015 adalah dengan pemberiaan pakan yang ditambahkan ekstrak akar jeruju, hasil yang diperoleh memperlihatkan bahwa terjadi peningkatan pertumbuhan pada ikan nila (Oreochromis niloticus) yang dipelihara. Penelitiaan terhadap Ekstrak daun jeruju juga pernah dilakukan oleh Septiani. G., dkk 2012 hasil penelitian mununjukan bahwa ekstrak daun jeruju berpotensi untuk menghambat pertumbuhan Vibrio harveyi. Penelitian ini menunjukan bahwa tumbuhan jeruju mempunyai manfaat yang baik untuk pertumbuhan dan kesehatan ikan. Penelitiaan tumbuhan sudah mulai banyak dilakukan tetapi banyak pada bagian daunnya sedangkan akar masih sangat sedikit.

Berdasarkan penelitiaan inilah peneliti tertarik untuk melakukan penelitiaan kembali pada tumbuhan jeruju dengan mengambil akar pada tumbuhan tersebut yang diaplikasikan menggunakan jenis ikan yang berbeda. Tumbuhan jeruju di Kabupaten Seruyan belum termanfaatkan dan bahkan tumbuh liar disekitar jalan. Dengan adanya penelitiaan ini diharapkan bisa memberikan alternatif bahan yang dapat ditambahkan pada pakan sehingga dapat meningkatkan pertumbuhan ikan dan produksi ikanpun dapat meningkat.Penelitiaan ini bertujuan untuk Mengetahui pengaruh pemberian ekstrak akar jeruju untuk meningkatkan laju pertumbuhan dan kelangsungan hidup ikan patin djambal (Pangasius djambal).

\section{RUANG LINGKUP}

Dalam penelitiaan ini permasalahan mencakup: 
1. Belum dimanfaatkannya tumbuhan jeruju di Kabupaten Seruyan.

2. Batasan - batasan penelitiaan ini adalah pengamatan dilakukan hanya pada ikan patin djambal (Pangasius djambal) dan hanya bagian akar jeruju saja yang digunakan.

3. Rencana hasil yang didapat pada penelitiaan ini adalah diharapkan akan adanya bahan yang dapat dijadikan alternatif yang ditambahkan pada pakan sehingga nantinya dapat meningkatkan pertumbuhan ikan patin djambal (Pangasius djambal).

\section{BAHAN DAN METODE}

Ikan uji yang digunakan dalam penelitian ini adalah benih ikan patin djambal (Pangasius djambal) sebanyak 180 ekor dengan ukuran 5-10 cm/ekor dengan kepadatan 15ekor/bak. Tumbuhan jeruju yang digunakan diperoleh di Kuala Pembuang Kabupaten Seruyan. Penelitiaan ini dilaksanakan pada bulan oktober- desember 2017. Metode yang digunakan dalam penelitiaan ini adalah Rancangan Acak Lengkap (RAL) dengan 4 perlakuan dan 3 kali ulangan. Perlakuan tersebut adalah :

A : Pemberiaan ekstrak sebanyak $100 \mathrm{gr} / \mathrm{kg}$ pakan

B : Pemberiaan ekstrak sebanyak $75 \mathrm{gr} / \mathrm{kg}$ pakan

$\mathrm{C}$ : Pemberiaan ekstrak sebanyak $50 \mathrm{gr} / \mathrm{kg}$ pakan

D : Tanpa pemberian ekstrak (kontrol).

Sebelum masa pemeliharaan ikan patin djambal (Pangasius djambal) diaklimatisasi terlebih dahulu selama 2 minggu untuk menyesuaikan kondisi ikan dengan lingkungannya. Pada masa aklimatisasi ini ikan masih belum diberi pakan uji. Prosedur pelaksanan penelitian ini adalah sebagai berikut :

\subsection{Persiapan Pakan Uji.}

Sebelum pakan diberikan kepada ikan uji maka pakan harus dipersiapkan terlebih dahulu, yaitu :

1) Pembuatan Ekstrak akar jeruju

Tumbuhan jeruju yang digunakan merupakan tumbuhan liar yang ada disekitar pinggir jalan. Tumbuhan jeruju tersebut dikumpulkan untuk diambil akarnya, setelah akar jeruju terkumpul, kemudian dibersihkan terlebih dahulu agar kotoran yang menempel pada akar tersebut bisa hilang. Setelah bersih haluskan akar tersebut sampai halus. Kemudian ditimbang sesuai perlakuan yang digunakan. Ekstrak akar jeruju diperoleh dengan mencampurkan serbuk akar yang sudah diperoleh dengan aquadest. Setelah itu dilakukan penyaringan terhadap hasil campuran tersebut. Hasil saringan inilah yang akan digunakan untuk campuran pakan yang diberikan pada ikan uji selama masa pemeliharaan.

2) Pembuatan Pakan Uji

Ekstrak yang terkumpul dicampurkan dengan pakan komersil dengan cara ekstrak akar jeruju disemprotkan kepada pakan yang digunakan secara merata setelah itu dikeringkan anginkan sampai pakan tersebut benar-benar kering.

\subsection{Pemberiaan Pakan Uji}

Pakan uji yang telah siap, diberikan kepada ikan dengan metode dibatasi yaitu 5\% dengan frekuensi pemberiaan pakan sebanyak $3 \mathrm{kali}$, yaitu pagi, siang dan sore hari.

\subsection{Parameter Uji}

Parameter yang diukur pada penelitiaan ini adalah :

1. Laju Pertumbuhan Relatif

Perhitungan laju pertumbuhan relatif dihitung berdasarkan rumus Effendi (1997) dalam Salsabila.A.,dkk (2013) yaitu (1) :

$$
\text { RGR }=\frac{\text { Wt }-W o}{W 0 \times t} x \mathbf{1 0 0} \%
$$

Keterangan: RGR : Relative Growth Rate(\%/hari)

$$
\text { Wt : Biomassa ikan akhir (gram) }
$$

Wo : Biomassa ikan awal (gram)

$\mathrm{t} \quad$ : lama penelitian (hari)

2. Efisiensi Pemanfaatan Pakan

Parameter ini dihitung berdasarkan rumus Tacon (1987) dalam Salsabila. A., dkk (2013) yaitu (2) :

$$
E P P=\frac{W t-W o}{F} \times 100 \%
$$

Keterangan: EPP : Efisiensi pemanfaatan pakan $(\%)$

Wt : Biomassa ikan akhir (gram)

Wo : Biomassa ikan awal (gram)

F : pakan yang dikonsumsi (gram)

3. Kelangsungan Hidup Ikan

Kelangsungan hidup dihitung dengan menggunakan rumus (Effendi, 2002) dalam minati 2016 yaitu (3) :

$$
\mathrm{SR}=\frac{\mathrm{Nt}}{\mathrm{N} \mathbf{0}} \times 100 \%
$$

Keterangan: SR : Derajat kelangsungan hidup (\%)

$\mathrm{Nt}$ : Jumlah ikan hidup pada akhir pemeliharaan (ekor)

No : Jumlah ikan pada awal pemeliharaan (ekor)

\section{Kualitas Air}

Pengamatan kualitas air selama masa pemeliharaan meliputi parameter fisika dan kimia perairan yaitu suhu, $\mathrm{pH}, \mathrm{DO}, \mathrm{CO}_{2}$, dan $\mathrm{NH}_{3}$

Data yang diperoleh dianalisis dengan menggunakan uji anova untuk melihat pengaruh perlakuan yang diberikan terhadap parameter yang diukur dan jika ada pengaruh maka dilanjutkan dengan uji berganda Duncan 


\section{PEMBAHASAN}

Hasil dari kegiatan penelitiaan penggunaan ekstrak akar jeruju yang ditambahkan pada pakan ikan yang digunakan untuk meningkatkan laju pertumbuhan relatif dan kelangsungan hidup ikan patin djambal (Pangasius djambal) dapat dilihat pada tabel 1 dan data kualitas air selama masa pemeliharaan dapat dilihat pada tabel 2 dibawah ini.

Tabel 1. Rerata Pertumbuhan Relatif, Efesiensi Pemanfaatan Pakan (EPP) dan Survival Rate (SR) Ikan Patin Djambal (Pangasius djambal) Selama masa pemeliharaan

\begin{tabular}{lccccc}
\hline \multicolumn{1}{c}{ Parameter Uji } & A & B & C & D & Satuan \\
\hline RGR & $3.62 \pm 0.09^{\mathrm{a}}$ & $3.34 \pm 0.15^{\mathrm{b}}$ & $2.29 \pm 0.17^{\mathrm{b}}$ & $1.46 \pm 0.11^{\mathrm{c}}$ & $\% / \mathrm{hari}$ \\
EPP & $28.48 \pm 1.66^{\mathrm{a}}$ & $22.82 \pm 0.36^{\mathrm{b}}$ & $18 . .52 \pm 1.91^{\mathrm{c}}$ & $5.65 \pm 3.46^{\mathrm{d}}$ & $\%$ \\
SR & $94.07 \pm 4.85^{\mathrm{a}}$ & $88.89 \pm 7.50^{\mathrm{a}}$ & $82.96 \pm 4.94^{\mathrm{a}}$ & $52.22 \pm 4.15^{\mathrm{b}}$ & $\%$ \\
\hline
\end{tabular}

Keterangan : Angka yang diikuti huruf superscript yang sama menunjukan tidak ada perbedaan sedangkan huruf super script yang berbeda menunjukan adanya perbedaan $(\mathrm{P}<0.01)$

Tabel 2. Data Kualitas Air Selama Masa Pemeliharaan

\begin{tabular}{lcc}
\hline \multicolumn{1}{c}{ Parameter Uji } & Nilai & Satuan \\
\hline Suhu & $26.5-30.3$ & ${ }^{\circ} \mathrm{C}$ \\
$\mathrm{pH}$ & $6.89-7.00$ & - \\
Oksigen Terlarut $(\mathrm{DO})$ & $1.06-1.18$ & $\mathrm{Mg} / 1$ \\
Karbondioksida $\left(\mathrm{CO}_{2}\right)$ & $0.72-0.87$ & $\mathrm{Mg} / 1$ \\
Amoniak $\left(\mathrm{NH}_{3}\right)$ & $0.01-0.02$ & $\mathrm{Mg} / 1$ \\
\hline
\end{tabular}

\subsection{Laju Pertumbuhan Relatif}

Berdasarkan Tabel 1 terlihat bahwa laju pertumbuhan ikan patin djambal (Pangasius djambal) yang tertinggi terjadi pada perlakuan A yaitu 3.62\%/hari kemudian diikuti perlakuan B yaitu 3.34\%/hari dan perlakuan C $(2.29 \%$ /hari) dan yang terendah perlakuan D (1.46\%/hari). Jika dilihat dari hasil yang diperoleh, laju pertumbuhan pada setiap perlakuan berbeda - beda hal ini menunjukan bahwa pemberiaan akar jeruju pada pakan mampu meningkatkan pertumbuhan pada ikan uji, Pakan adalah salah satu faktor yang sangat berpengaruh terhadap pertumbuhan ikan karena pakan berfungsi sebagai pemasok energi untuk meningkatkan pertumbuhan dan mempertahankan kelansungan hidup. Ketersediaan pakan merupakan salah satu persyaratan mutlak bagi berhasilnya usaha budidaya ikan (Asma, dkk. 2016). Adanya perbedaan laju pertumbuhan pada perlakuan diduga karena kandungan kimia akar jeruju memberikan dampak positif pada ikan uji. Kandungan kimia akar jeruju terdiri dari saponin, asam amino, flavonoid dan polifenol (Saroya dan Ampritpal, 2011).

Gugus asam amino pada akar tumbuhan jeruju diekskresi menjadi amino dan residu rantai karbondioksida melalui siklus asam trikaboksilat hingga menghasilkan energy, atau sebagian dirubah menjadi lemak dan karbohidrat sehingga dapat mempengaruhi pertumbuhan (Gita, M. 2011). Flavonoid merupakan senyawa metabolit sekunder yang dihasilkan tanaman, senyawa ini memberikan pengaruh biologi bagi kenaikan pertumbuhan, daya tahan tubuh, anti stress, anti bakteri, jamur dan anti virus serta perangsang lainnya (Soetarno dkk., 2004 dalam Diniatik, 2016). Keberadaan kedua senyawa pada akar jeruju yang diberikan pada pakan mempengaruhi laju pertumbuhan relatif pada ikan patin (Pangasius djambal).
Laju pertumbuhan yang terjadi menunjukan bahwa ikan patin djambal (Pangasius djambal) yang dipelihara mampu memanfaatkan nutrient pada pakan yang diberikan untuk disimpan kedalam tubuh dan mengkonversikannya menjadi suatu energi, hal ini sejalan dengan pendapat Hidayatullah, dkk (2011) yang menyatakan bahwa pemanfaatan energy dari makanan berupa pellet jika diberikan dengan baik maka energi akan tersedia lebih banyak digunakan untuk pertumbuhan atau penambahan berat. Pakan adalah faktor eksternal yang merupakan unsur utama yang menjadikan protein sebagai sumber energy bagi pertumbuhan dan kelangsungan hidup, karena fungsi pakan pada ikan sangat terkait dengan aktivitas enzim pencernaan yang keberadaannya sangat bervariasi dan dipengaruhi oleh ukuran (fisiologis), umur ikan dan organ spesifik selama masa pertumbuhan serta musim (Hepher, 1988 dalam Aslianti, dkk, 2014)

Makanan dimanfaatkan oleh ikan pertama-tama digunakan untuk memelihara tubuh dan menggantikan alat-alat tubuh dang menggantikan alat-alat tubuh yang rusak setelah itu baru kelebihan makanan yang tersisa dipergunakan untuk pertumbuhan. Faktor utama yang mempengaruhi pertumbuhan adalah ketersediaan pakan baik secara kuantitatif maupun kualitas pakan atau jenis pakan (Halver, 1979 dalam masjudi, dkk. 2016)

\subsection{Efisiensi Pemanfatan Pakan}

Berdasarkan hasil penelitiaan nilai efisiensi pemanfatan pakan pada perlakuan A $(28.48 \%)$ lebih tinggi dibanding perlakuan B $(22.82 \%)$, perlakuan C $(18.52 \%)$ dan perlakuan D $(5.65 \%)$. Tingginya nilai efisiensi pemanfaatan pakan pada perlakuan A diduga karena kemampuan ikan uji dalam memanfaatkan pakan pada perlakuan ini lebih tinggi dibanding perlakuan lain. 
Menurut marzuqi. dkk (2012) efisiensi pakan menunjukan seberapa besar pakan yang dimanfaatkan oleh ikan. Nilai efisiensi pakan yang rendah menunjukan bahwa ikan memerlukan pakan dengan jumlah yang lebih banyak untuk meningkatkan beratnya, hanya sebagian kecil energy dari pakan yang diberikan digunakan untuk pertumbuhan ikan, tidak semua makanan yang dimakan oleh ikan digunakan untuk pertumbuhan, sebagian besar energy dari makanan digunakan untuk pemeliharaan, sisanya untuk aktivitas, pertumbuhan dan reproduksi.

Nilai efisiensi pemenfaatan pakan yang diperoleh pada penelitian ini berkisar antara 5.65 - 28.48\%. Berdasarkan hasil analisis menunjukan bahwa pemberian akar jeruju pada pakan memberikan pengaruh yang sangat nyata terhadap efisiensi pemanfaatan pakan. Menurut Watanabe 1988 dalam Musfira, 2016 faktor penting yang menentukan pertumbuhan dan efisiensi pakan adalah jenis dan komposisi pakan yang sesuai dengan kebutuhan ikan. Jenis dan komposisi pakan harus sesuai dengan ketersediaan endoenzim dalam saluran pencernaan ikan, sehongga pakan akan dicerna dengan baik dan energy yang tersedia untuk pertumbuhan lebih besar.

\subsection{Kelangsungan Hidup Ikan Patin djambal (Pangasius djambal)}

Berdasarkan hasil penelitiaan menunjukan bahwa nilai kelangsungan hidup ikan pada perlakuan yang diberi pakan dengan akar jeruju berbeda dengan perlakuan yang tidak diberikan pakan dengan akar jeruju, hal ini menunjukan bahwa akar jeruju juga mampu meningkatkan kelangsungan hidup ikan, diduga karena senyawa kimia yang ada pada akar jeruju bereaksi positif terhadap ikan sehingga kekebalan tubuh ikan meningkat dan kelangsungan hidup ikan uji tinggi dibanding perlakuan tanpa ekstrak akar jeruju. Hasil yang diperoleh pada saat pemeliharaan ini sesuai dengan pendapat Saptiani (2012) bahwa salah satu fungsi ekstrak jeruju adalah untuk mengendalikan serangan bakteri dan untuk meningkatkan kekebalan tubuh ikan.

Berdasarkan hasil analisa data, terlihat bahwa dengan penambahan ekstrak akar jeruju pada pakan berpengaruh nyata terhadap kelangsungan hidup ikan patin djambal (Pangasius djambal) tetapi penggunaan dosis yang berbeda tidak memberikan pengaruh yang berbeda terhadap kelangsungan hidup ikan patin djambal (Pangasius djambal) yang dipelihara. Selain kandungan senyawa kimia yang ada dalam ekstrak akar jeruju, kelansungan hidup ikan patin djambal (Pangasius djambal) diduga juga dipengaruhi oleh kemampuan ikan untuk memanfaatkan ruang gerak yang tersedia, pemberian pakan yang tepat dan kualtis air yang dapat ditolerir oleh ikan patin djambal (Pangasis djambal) yang dipelihara. Menurut Widya (1993) dalam Nindiyanastiti, dkk (2014) kelangsungan hidup ikan juga dipengaruhi oleh padat penebaran ikan, jika padat penebaran tinggi maka konsumsi oksigen akan menjadi bahan buangan metabolisme ikan akan semakin tinggi dan akan menghambat pertumbuhan ikan.

\subsection{Kualitas Air}

Data kualitas air selama masa pemeliharaan dapat dilihat pada tabel 2. Berdasarkan tabel tersebut kualitas air selama masa pemeliharaan masih layak untuk mendukung pertumbuhan dan kelangsungan hidup ikan patin djambal (Pangasius djambal). Hasil penelitian menunjukan bahwa suhu berkisar antara $26.5-30.3{ }^{\circ} \mathrm{C}$, kondisi suhu ini masih dianggap standar untuk pertumbuhan ikan patin hal ini sejalan dengan pendapat Minggawati, 2012 yang menyatakan bahwa suhu standar untuk pertumbuhan ikan patin adalah $25-32^{\circ} \mathrm{C}$. suhu merupakan salah satu variabel kualitas air yang bersifat fisik dan memiliki peran penting dalam kehidupan semua organisme air. Suhu dapat mempengaruhi aktivitas metabolisme ikan, semakin tinggi suhu maka akan semakin cepat pula perairan mengalami kejenuhan akan oksigen (Asmawi, 1983 dalam Leunufna, 2012). pH air selama masa pemeliharaan berkisar antara $6.89-7.00$. kisaran $\mathrm{pH}$ pada media pemeliharaan masih dalam batas toleransi ikan,hal ini sejalan dengan pendapat Effendi, 2003 dalam Warsa dan Nastiti (2010) mengatakan bahwa $\mathrm{pH}$ yang baik untuk budidaya ikan patin adalah berkisar antara $6.5-7.0 \mathrm{pH}$ merupakan suatu pembatas dalam suatu pertumbuhan ikan bahkan kelangsungan hidup ikan (Kordi dan Tacung, 2007 dalam Leunufna, 2012). Oksigen terlarut (DO) pada media pemeliharaan berkisar antara $1.06-1.18 \mathrm{mg} / \mathrm{l}$,Karbondioksida $\left(\mathrm{CO}_{2}\right)$ $0.72-0.87 \mathrm{mg} / \mathrm{l}$ dan amoniak $\left(\mathrm{NH}_{3}\right) 0.01-0.02 \mathrm{mg} / \mathrm{l}$. nilai kualitas air selama pemeliharaan dianggap masih standar untuk kegiatan budidaya ikan patin. Oksigen terlarut (DO) dibutuhkan oleh semua jasad hidup untuk pernapasan, proses metabolisme atau pertukaran zat yang kemudian menghasilkan energi untuk pertumbuhan dan pembiakan.selain itu, oksigen juga dibutuhkan untuk oksidasi dan anoeganik dalam proses aerobic (Salmin, 2005 dalam Hengga, E. 2012).

\section{KESIMPULAN}

Berdasarkan penelitian yang telah dilakukan maka dapat disimpulkan bahwaakar jeruju dapat dijadikan sebagai salah satu bahan yang dapat ditmbahkan pada pakan untuk meningkatkan laju pertumbuhan relatif dan kelangsungan hidup ikan patin djambal (Pangasius djambal). Dosis terbaik adalah 100 gram $/ \mathrm{kg}$ pakan.

\section{SARAN}

Adanya penelitian lanjutan tentang penggunaan tumbuhan jeruju, bisa digunakan untuk jenis ikan yang berbeda atau menggunakan bagian jeruju yang berbeda. 


\section{DAFTARA PUSTAKA}

Warsa, A dan Nastiti, A.S. 2010. Kelayakan habi tat untukpenebaran ikan patin (Pangasius djambal)diDanau Teluk, Jambi. Prosiding Seminar Nasional Ikan VI. Masyarakat Ikhtiologi Indonesia.

Aslianti, T, Nasukha A, Irwan, S. 2014. Perkembangan Tulang Belakang dan Aktifitas Enzim Protease Larva Ikan Bandeng, Chanos - chanos forsskal Yang Dipelihara Pada Media Berbeda. Jurnal Ilmu Teknologi Kelautan Tropis. 6 (1).

Asma, N., Z.A. Muchlisin dan I. Hasri. 2016. Pertumbuhan dan Kelangsungan Hidup Benih Ikan Peres (Osteochilus vittatus) pada Ransum Harian yang Berbeda. Jurnal Ilmiah Mahasiswa Kelautan dan Perikanan Unsyiah. 1(1) .

Diniatik, 2016. Potensi Penangkapan Radikal Bebas Hasil Hidrolisis Ekstrak Etanol Daun Kepel (Stelechocarpus burahol), (Bl.) Hook f. dan Th) Dengan Metode DPPH. Media Farmasi Vo. 13 No.2. Universitas Muhammadiyah. Purwokerto.

Febrianty, E. 2011. Produktivitas Alga Hydrodictyon Pada Sistem Perairan Tertutup. (Closed system). Bogor.

Gita,M.2011http://masayugita.blogspot.com/2011/11/keb utuhan-asam-amino-bagi-ikan.html

Hidayatullah, A dan N. Hafizah. 2011. Perbandingan Tingkat Pertumbuhan Strain Ikan Tilapia Yang Dipelihara dalam Baskom Plastik dengan Pemberian Makanan Tambahana. STIPER Amuntai. Hulu Sungai Besar.

Leunufna, 2012.Pengaruh Salinitas Yang Berbeda Terhadap Kelangsungan Hidup, Pertumbuhan dan Efisiensi Pemberian Pakan Benih Ikan Nila Merah. Universitas Pandjajaran. Bandung

Marzuqi, M., N. W. Astuti dan K. Suwirya. 2011. Pengaruh Kadar Protein Pakan Terhadap Pertumbuhan Ikan Kerapu Macan (Epinephelus fuscoguttatus). BBPP Budidaya Laut Gondol,Bali. Vol.4 (1) .

Masjudi, h, dkk. 2016. Kajian Tingkat Stress Ikan Tapah (Wallago leeri) Yang Dipelihara Dengan Pemberian Pakan dan Suhu Yang Berbeda. Jurnal Berkala Perikanan Terubuk. Vol.44 No.3.

Minggawati, I., Saptono. 2011. Analisa Usaha Pembesaran Ikan Patin Jambal (Pangasius djambal) dalam Kolam di desa Sidomulyo Kabupaten Kuala Kapuas. Me dia Sains 3 (1).

Minati. 2016. Pengaruh Padat Tebar Yang Berbeda Terhadap Kelangsungan hidup dan Pertumbuhan Ikan Betok (Anabas testudineus) Yang Dipelihara Di Bak P;astik. Universitas Darwan Ali. Kuala Pembuang.

Musfira. S. 2016. Pengaruh Substitusi Ikan Dengan Tepung Kepala Udang Terhadap Pertumbhan Ikan Nila (Oreochromis niloticus). Universitas Darwan Ali. Kuala Pembuang.
Nindiyanastiti, dkk .2014. http://nindiyanastiti.blogspot.co.id/2014/11/Budida yaLobster-html

Rahayu, M. 2015. Penambahan Ekstrak Akar Daruju Pada Pakan Dalam Meningkatkan Sintasan Benih Ikan Nila (Oreochromis niloticus). Fakultas Perikanan dan Ilmu Kelautan. Universitas Darwan Ali. Kuala Pembuang.

Saroya, S., dan Amritpal. 2011. Herbalism, Phytochemistry and Etnopharmacology

Septiani, G., S.B. Prayitno dan S. Anggoro, 2012. Daya Hambat Ekstrak Jeruju (Acanthus ilicifollius) Terhadap Pertumbuhan Vibrio harvey. Simposium Nasional Kimia Bahan Alam XIX (SIMNASKBA2011). Himpunan Kimia Bahan Alam. Samarinda. 